\title{
SOME PHOSPHORUS TEST VALUES AND FRACTIONS OF INORGANIC PHOSPHORUS IN SOILS
}

\author{
ARMi KaILA \\ University of Helsinki, Department of Agricultural Chemistry
}

Received February 12, 1965

The attempts to estimate the phosphorus conditions of a soil with various kinds of rapid chemical soil tests have usually failed. This is easy to understand, if the numerous factors are taken into account which may influence the uptake of phosphorus by plants. Most of the rapid tests only give a more or less poor idea either of the intensity factor or of the capacity factor of the soil phosphorus status, although in addition to these both at least some indicator of the phosphate retention capacity of the soil would be necessary $(15,16)$.

Relatively little is known about the kind of soil phosphorus on which the various test values will depend. Acid solutions are supposed to extract phosphorus mainly bound by calcium, and alkaline solutions are likely to dissolve phosphorus bound by the sesquioxides. Most tests will probably include an indefinite and variable part of these forms. Recently, attempts have been made to study this problem by comparing the test values with the results of the fractionation of soil phosphorus $(2,14$, 18). Al-AbBas and Barber (1) have even developed a soil test for alkaline soils on the basis of their studies which showed that the phosphorus taken up by plants in pot experiments was highly correlated with the iron-bound phosphorus fraction, while the water-soluble phosphorus also contributed significantly to the variations observed.

Most of the studies on the correlation of phosphorus availability by chemical soil tests with the inorganic phosphorus fractions are performed on a basis of a relatively small material, usually less than 30 soil samples. In the present work the dependence of the variation in the test values on the variation of the amounts of differently bound phosphorus in soil is estimated on a basis of a material consisting of 346 samples of mineral soils. The soil tests studied are the so called Bray 1 test (3), the procedure of OLSEN et al. (13) with $\mathrm{NaHCO}_{3}$, and the determinations of the phosphorus extracted by acid ammonium acetate and by acetic acid. 


\section{Material and methods}

In order to get a material in which the variation of the phosphorus conditions was as large as possible, not only samples of plough layer but also samples of deeper layers and from virgin soils were collected. All the samples were air-dried at room temperature and ground to pass $2 \mathrm{~mm}$. On the basis of the results of the mechanical analysis, the samples were grouped to sand and finesand soils, loam and silt soils, and clay soils (cf. 8). The number of the samples in the various groups may be seen in Table 1.

Table 1. Number of samples, pH, and fractions of inorganic phosphorus in the groups of soil samples. (Means with the confidence limits at the 95 per cent level)

\begin{tabular}{|c|c|c|c|c|c|c|}
\hline & \multirow{2}{*}{$\begin{array}{c}\text { Number } \\
\text { of } \\
\text { samples }\end{array}$} & \multirow[t]{2}{*}{$\mathrm{pH}$} & \multicolumn{4}{|c|}{ P ppm extracted by } \\
\hline & & & $\mathrm{NH}_{4} \mathrm{Cl}$ & $\mathrm{NH}_{4} \mathrm{~F}$ & $\mathrm{NaOH}$ & $\mathrm{H}_{2} \mathrm{SO}_{4}$ \\
\hline \multicolumn{7}{|l|}{ Sand and finesand soils } \\
\hline \multirow[t]{2}{*}{ Topsoil, cultivated } & 52 & $5.4 \pm 0.1$ & $4 \pm 0.7$ & $128 \pm 31$ & $154 \pm 30$ & $124 \pm 24$ \\
\hline & 16 & $4.6 \pm 0.4$ & $4 \pm 1.8$ & $17 \pm 5$ & $49 \pm 15$ & $87 \pm 55$ \\
\hline Subsoil & 34 & $5.2 \pm 0.2$ & $1 \pm 0.6$ & $47 \pm 11$ & $71 \pm 16$ & $134 \pm 38$ \\
\hline All samples & 102 & $5.2 \pm 0.1$ & $3 \pm 0.5$ & $83 \pm 18$ & $110 \pm 18$ & $130 \pm 19$ \\
\hline \multicolumn{7}{|l|}{ Loam and silt soils } \\
\hline \multirow{2}{*}{$\begin{array}{cl}\text { Topsoil, } & \text { cultivated } \\
\text { virgin }\end{array}$} & 68 & $5.2 \pm 0.1$ & $4 \pm 1.5$ & $71 \pm 15$ & $147 \pm 18$ & $224 \pm 29$ \\
\hline & 5 & $4.5 \pm 0.3$ & $2 \pm 2.0$ & $26 \pm 20$ & $144 \pm 170$ & $189 \pm 135$ \\
\hline Subsoil & 25 & $5.5 \pm 0.3$ & $0.5 \pm 0.4$ & $14 \pm 7$ & $91 \pm 40$ & $96 \pm 81$ \\
\hline All samples & 98 & $5.2 \pm 0.1$ & $3 \pm 1.0$ & $54 \pm 12$ & $132 \pm 17$ & $245 \pm 29$ \\
\hline \multicolumn{7}{|l|}{ Clay soils } \\
\hline \multirow{2}{*}{$\begin{array}{cl}\text { Topsoil, } & \text { cultivated } \\
\text { virgin }\end{array}$} & 84 & $5.3 \pm 0.1$ & $3 \pm 0.4$ & $78 \pm 13$ & $202 \pm 23$ & $213 \pm 20$ \\
\hline & 4 & $6.1 \pm 2.2$ & $2 \pm 1.3$ & $20 \pm 20$ & $78 \pm 40$ & $234 \pm 245$ \\
\hline Subsoil & 58 & $5.6 \pm 0.3$ & $1 \pm 0.2$ & $14 \pm 5$ & $125 \pm 32$ & $267 \pm 40$ \\
\hline All samples & 146 & $5.4 \pm 0.1$ & $2 \pm 0.3$ & $51 \pm 9$ & $168 \pm 19$ & $235 \pm 20$ \\
\hline
\end{tabular}

The $\mathrm{pH}$ of the soil was mesured in $1: 2.5$ suspension in $0.01 \mathrm{M} \mathrm{CaCl}_{2}$. The fractions of inorganic phosphorus were determined by the procedure of CHANG and JACKSON (4), instead of a neutral $\mathrm{NH}_{4}-\mathrm{F}$ solution a slightly alkaline extractant was used. Also the $\mathrm{NH}_{4} \mathrm{Cl}$-soluble fraction was determined. The results are recorded in Table 1 as mean values for the various groups.

The Bray 1 test, or estimation of the phosphorus extracted by $0.03 \mathrm{~N} \mathrm{NH}_{4} \mathrm{~F}-$ $0.025 \mathrm{~N} \mathrm{HCl}$ (3), was modified by changing the ratio of soil to solution to 1 to 10 . The period of shaking was 1 minute.

The Olsen test (13) was performed by extracting the soil samples in the ratio of 1 to 20 with $0.5 \mathrm{M} \mathrm{NaHCO}_{3}$ buffered to $\mathrm{pH} 8.5$, for half an hour. Washed, activated charcoal was used for the elimination of the colour of the extract.

The acetic acid test, chosen to represent the determination of available phosphorus by the weakly dissociated acid solutions, was carried out by extracting thesoil samples for half an hour with $0.5 \mathrm{~N}$ acetic acid; the ratio of soil to solution was 1 to 10 . 
The extractant of the acetate test was the acid ammonium acetate solution used in Finland in the soil survey work for the determination of available phosphorus, potassium and exchangeable calcium. The solution is $1 \mathrm{~N}$ with respect to acetic acid and $0.5 \mathrm{~N}$ with respect to ammonium acetate, the $\mathrm{pH}$ of the solution is 4.65 . The ratio of soil to solution was 1 to 10 and the period of shaking one hour.

Table 2. Phosphorus test values, $\mathrm{P}$ ppm, in the groups of soil samples. Means with the confidence limits at the 95 per cent level.

\begin{tabular}{|c|c|c|c|c|}
\hline & $\begin{array}{c}\text { Bray } 1 \\
\text { test }\end{array}$ & $\begin{array}{l}\text { Olsen's } \\
\text { test }\end{array}$ & $\begin{array}{c}\text { Acetic acid } \\
\text { test }\end{array}$ & $\begin{array}{l}\text { Acetate } \\
\text { test }\end{array}$ \\
\hline \multicolumn{5}{|l|}{ Sand and finesand soils } \\
\hline \multirow{2}{*}{$\begin{array}{c}\text { Topsoil, cultivated } \\
\text { virgin }\end{array}$} & $75 \pm 16$ & $47 \pm 8$ & $18 \pm 6$ & $12 \pm 3$ \\
\hline & $8 \pm 2$ & $21 \pm 5$ & $4 \pm 3$ & $6 \pm 2$ \\
\hline Subsoil & $19 \pm 6$ & $10 \pm 3$ & $3 \pm 1$ & $2 \pm 1$ \\
\hline All samples & $46 \pm 10$ & $31 \pm 6$ & $11 \pm 3$ & $8 \pm \mathbf{2}$ \\
\hline \multicolumn{5}{|l|}{ Loam and silt soils } \\
\hline \multirow{2}{*}{$\begin{array}{c}\text { Topsoil, cultivated } \\
\text { virgin }\end{array}$} & $42 \pm 9$ & $35 \pm 6$ & $13 \pm 5$ & $10 \pm 4$ \\
\hline & $13 \pm 13$ & $28 \pm 33$ & $2 \pm 1$ & $6 \pm 5$ \\
\hline Subsoil & $8 \pm 3$ & $15 \pm 7$ & $48 \pm 23$ & $2 \pm 1$ \\
\hline All samples & $32 \pm 7$ & $30 \pm 5$ & $22 \pm 7$ & $7 \pm 3$ \\
\hline \multicolumn{5}{|l|}{ Clay soils } \\
\hline \multirow{2}{*}{$\begin{array}{cl}\text { Topsoil, } & \text { vultivated } \\
\text { virgin }\end{array}$} & $38 \pm 5$ & $39 \pm 4$ & $14 \pm 3$ & $8 \pm 1$ \\
\hline & $6 \pm 6$ & $14 \pm 3$ & $8 \pm 16$ & $3 \pm 2$ \\
\hline Subsoil & $6 \pm 2$ & $16 \pm 3$ & $26 \pm 8$ & $3 \pm 1$ \\
\hline All samples & $25 \pm 4$ & $29 \pm 3$ & $19 \pm 4$ & $6 \pm 1$ \\
\hline Average values & $33 \pm 4$ & $30 \pm 3$ & $17 \pm 3$ & $\mathbf{7} \pm \mathbf{1}$ \\
\hline
\end{tabular}

\section{Results}

The test values obtained are reported in Table 2 as the means for the various soil groups. The average values for all samples show that the Bray 1 test and the Olsen test gave the highest results for this material, while the acetic acid extracted somewhat more than one half and the acetate test from one fifth to one fourth of the amount of phosphorus found by these two tests. In the various groups of the soils, however, the order may be quite different.

Bray 1 test has given the highest mean result in the surface samples of the cultivated sand and finesand soils. It is significantly higher than the corresponding Olsen test value. In the groups of the loam and silt soils, and clay soils these test values are, on the average equal. The mean values of the acetic acid test and the acetate test are of the same order in the surface samples of the coarser soils, but in the clay soils, the former has given a somewhat higher result.

In the samples from the virgin soil and subsoil the test values are lower than those from the surface layer of the cultivated soils, except the acetic acid test values 
which tend to be markedly higher in the subsoil samples of the loam and silt soils and clay soils than in the plough layer samples of the corresponding kind of soil.

The average Olsen test value is equal for the 102 samples of sand and finesand soils, the 98 samples of loam and silt soils, and the 146 samples of clay soils. The same is true with the acetate test. The Bray 1 test, however, has a higher average for the sand and finesand soils than for the clay soils, and the acetic acid test shows the lowest average for the sand and finesand soils.

Table 3. Correlation coefficients for the relation between the test values

\begin{tabular}{ccccc}
\hline Correlation between & $\begin{array}{c}\text { Sand and } \\
\text { finesand } \\
\text { soils }\end{array}$ & $\begin{array}{c}\text { Loam and } \\
\text { silt soils }\end{array}$ & Clay soils & All samples \\
& & & \\
Bray 1 test and & & & \\
Olsen's test & $0.88^{* * *}$ & $0.90^{* * *}$ & $0.85^{* * *}$ & $0.85^{* * *}$ \\
Acetate test & $0.77^{* * *}$ & $0.74^{* * *}$ & $0.73^{* * *}$ & $0.70^{* * *}$ \\
Acetic acid test & $0.75^{* * *}$ & 0.09 & -0.11 & $0.17^{* *}$ \\
Acetate test & $0.87^{* * *}$ & $0.76^{* * *}$ & $0.79^{* * *}$ & $0.77^{* * *}$ \\
Acetic acid test & $0.80^{* * *}$ & 0.03 & $-0.21^{*}$ & $0.13^{*}$ \\
Olsen's test and & & & & \\
Acetic acid test & $0.92^{* * *}$ & $0.30^{* *}$ & -0.02 & $0.34^{* * *}$ \\
& & & & \\
\hline
\end{tabular}

The relation of the various test values was studied by calculating the linear correlation coefficients between them. These results are reported in Table 3 . In the group of the sand and finesand soils, all the test values appear to be fairly closely correlated with each other. In the groups of the soils of a finer texture, the acetic acid test values do not seem to be related with the results of the other tests, and also the relation in the whole material is very poor. The Bray 1 test and the Olsen test tend to be more closely correlated with each other than with the acetate test.

The main purpose of the present study is to find out to what extent the variation in the test values may be explained by the variation in the fractions of inorganic phosphorus in the soil. This was first examined by calculating the total linear correlation coefficients between the various test values and the fractions of phosphorus. These coefficients are listed in Table 4. It also contains the correlation coefficients for the relation between the test values and the soil $\mathrm{pH}$.

As can be expected, the Bray 1 test value is closely correlated with the $\mathrm{NH}_{4} \mathrm{~F}$ soluble P, particularly in the groups of loam and silt soils and sand and finesand soils. In the latter soils the connection with the alkali soluble $\mathrm{P}$ is fairly close, but in the former group and in the clay soils also the relation with $\mathrm{NH}_{4} \mathrm{Cl}$-soluble $\mathrm{P}$ is marked. The correlation with the acid-soluble fraction, or with the soil $\mathrm{pH}$ is negligible, except in the sand and finesand soils. In the whole material the relation is closest with the $\mathrm{NH}_{4} \mathrm{~F}$-soluble fraction. 
Table 4. Correlation coefficients for the relation between the test values and the fractions of inorganic phosphorus and soil $\mathrm{pH}$

\begin{tabular}{|c|c|c|c|c|c|c|}
\hline \multirow[t]{2}{*}{ Test } & \multirow[t]{2}{*}{ Soil group } & \multicolumn{4}{|c|}{ P extracted by } & \multirow[b]{2}{*}{$\mathrm{pH}$} \\
\hline & & $\mathrm{NH}_{4} \mathrm{Cl}$ & $\mathrm{NH}_{4} \mathrm{~F}$ & $\mathrm{NaOH}$ & $\mathrm{H}_{2} \mathrm{SO}_{4}$ & \\
\hline \multicolumn{7}{|c|}{ Bray 1} \\
\hline & Sand and finesand & $0.39 * * *$ & $0.89 * * * *$ & $0.79 * * *$ & $0.30^{* *}$ & $0.40^{* * *}$ \\
\hline & Loam and silt & $0.70^{* * *}$ & $0.97 * * *$ & $0.69 * * *$ & -0.07 & 0.06 \\
\hline & Clay & $0.65^{* * *}$ & $0.70^{* * *}$ & $0.48^{* * *}$ & -0.09 & -0.16 \\
\hline & All samples & $0.53^{* * *}$ & $0.87 * * *$ & $0.51 * * *$ & -0.04 & 0.07 \\
\hline \multicolumn{7}{|c|}{ Olsen } \\
\hline & Sand and finesand & $0.47 * * *$ & $0.78 * * *$ & $0.82 * * *$ & $0.36^{* * *}$ & $0.35^{* * *}$ \\
\hline & Loam and silt & $0.69^{* * *}$ & $0.90 * * *$ & $0.87 * * *$ & -0.03 & -0.06 \\
\hline & Clay & $0.56^{* * *}$ & $0.59 * * *$ & $0.75^{* * *}$ & -0.09 & $-0.29^{* *}$ \\
\hline & All samples & $0.54^{* * *}$ & $0.74^{* * *}$ & $0.74^{* * *}$ & 0.05 & -0.03 \\
\hline \multicolumn{7}{|c|}{ Acetate } \\
\hline & Sand and finesand & $0.53 * * *$ & $0.68 * * *$ & $0.78 * * *$ & $0.41 * * *$ & $0.46^{* * *}$ \\
\hline & Loam and silt & $0.93^{* * *}$ & $0.75^{* * *}$ & $0.52 * * *$ & 0.03 & $0.28^{* *}$ \\
\hline & Clay & $0.72^{* * *}$ & $0.50^{* * *}$ & $0.49 * * *$ & 0.01 & -0.08 \\
\hline & All samples & $0.80^{* * *}$ & $0.61 * * *$ & $0.46^{* * *}$ & 0.08 & $0.18^{* *}$ \\
\hline \multicolumn{7}{|c|}{ Acetic acid } \\
\hline & Sand and finesand & $0.48^{* * *}$ & $0.63^{* * *}$ & $0.71^{* * *}$ & $0.50^{* * *}$ & $0.45^{* * *}$ \\
\hline & Loam and silt & $0.27 * *$ & 0.06 & -0.16 & $0.64 * * *$ & $0.73^{* * *}$ \\
\hline & Clay & 0.12 & $-0.17^{*}$ & $-0.28 * *$ & $0.55^{* * *}$ & $0.70^{* * *}$ \\
\hline & All samples & $0.25 * * *$ & 0.10 & -0.01 & $0.59 * * *$ & $0.60^{* * *}$ \\
\hline
\end{tabular}

The results for the Olsen test differ mainly from those for the Bray 1 test in the somewhat more close correlation with the alkali-soluble fraction and the correspondingly lower correlation with the $\mathrm{NH}_{4} \mathrm{~F}$-soluble $\mathrm{P}$. Except in the group of the clay soils, the correlation coefficients between the test value and these fractions are of the same order.

The acetate test values are most closely correlated with the $\mathrm{NH}_{4} \mathrm{Cl}$-soluble $\mathrm{P}$, but for the sand and finesand soils in which the correlation with the alkali-soluble fraction appears to be the most marked. In this group also the connection with the acid-soluble $\mathrm{P}$ may be noteworthy.

The correlation coefficients between the acetic acid test values and the phosphorus fractions do not markedly differ from the corresponding values for the acetate test in the sand and finesand soils. In the other groups, and in the whole material the correlation appears to be indisputable only with the acid-soluble $\mathrm{P}$ and the soil $\mathrm{pH}$.

The examination was carried on by studying the multiple correlation between the variables. In Table 5 are reported the coefficents of determination, $\mathrm{r}^{2}$, for the relation between the test values and the $\mathrm{NH}_{4} \mathrm{~F}$-soluble $\mathrm{P}$, and the coefficients of multiple determinaton, $\mathrm{R}^{2}$, obtained when in addition the effects of the fractions of alkali-soluble $\mathrm{P}, \mathrm{NH}_{4} \mathrm{Cl}$-soluble $\mathrm{P}$ and acid-soluble $\mathrm{P}$, on the variation of the test values are taken into account.

In the sand and finesand soils of this material 80 per cent of the variation in the Bray 1 test values may be explained by the variation in the $\mathrm{NH}_{4} \mathrm{~F}$-soluble $\mathrm{P}$, 
Table 5. Coefficients of determination, $\mathrm{r}^{2}$, and multiple determination, $\mathrm{R}^{2}$, for the relation between the test values (1), and the fractions of inorganic $\mathrm{P}$ extracted by $\mathrm{NH}_{4} \mathrm{~F}(2)$, by $\mathrm{NaOH}(3)$, by $\mathrm{NH}_{4} \mathrm{Cl}(4)$, and by $\mathrm{HS}_{2} \mathrm{O}_{4}(5)$

\begin{tabular}{|c|c|c|c|c|c|}
\hline Test & Coefficient & $\begin{array}{c}\text { Sand and } \\
\text { finesand } \\
\text { soils }\end{array}$ & $\begin{array}{l}\text { Loam and } \\
\text { silt soils }\end{array}$ & Clay soils & All samples \\
\hline \multicolumn{6}{|c|}{ Bray 1} \\
\hline & $\mathrm{r}^{2} 12$ & 0.80 & 0.94 & 0.49 & 0.75 \\
\hline & $\mathrm{R}^{2}{ }_{1,23}$ & 0.83 & 0.95 & 0.54 & 0.76 \\
\hline & $\mathrm{R}^{2} 1,234$ & 0.83 & 0.95 & 0.70 & 0.78 \\
\hline & $\mathrm{R}^{2}{ }_{1,2345}$ & 0.83 & 0.95 & 0.70 & 0.78 \\
\hline \multicolumn{6}{|l|}{ Olsen } \\
\hline & $r^{2} 12$ & 0.61 & 0.81 & 0.35 & 0.55 \\
\hline & $\mathrm{R}^{2}{ }_{1,23}$ & 0.73 & 0.92 & 0.65 & 0.73 \\
\hline & $\mathrm{R}^{2} 1,234$ & 0.75 & 0.93 & 0.76 & 0.78 \\
\hline & $R^{2} 1,2345$ & 0.75 & 0.94 & 0.76 & 0.78 \\
\hline \multicolumn{6}{|c|}{ Acetate } \\
\hline & $\mathrm{r}^{2} 12$ & 0.46 & 0.56 & 0.25 & 0.38 \\
\hline & $\mathrm{R}^{2}{ }_{1,23}$ & 0.62 & 0.56 & 0.35 & 0.41 \\
\hline & $\mathrm{R}^{2}{ }_{1,234}$ & 0.67 & 0.89 & 0.65 & 0.75 \\
\hline & $\mathrm{R}^{2}{ }_{1,2345}$ & 0.68 & 0.90 & 0.69 & 0.77 \\
\hline \multicolumn{6}{|c|}{ Acetic acid } \\
\hline & $\mathrm{r}^{2} 12$ & 0.39 & 0.004 & 0.03 & 0.01 \\
\hline & $\mathrm{R}^{2}{ }_{1,23}$ & 0.52 & 0.08 & 0.08 & 0.01 \\
\hline & $\mathrm{R}^{2}{ }_{1,234}$ & 0.56 & 0.18 & 0.13 & 0.07 \\
\hline & $\mathrm{R}^{21,2345}$ & 0.62 & 0.57 & 0.34 & 0.44 \\
\hline
\end{tabular}

and 83 per cent of the variation by the variation in this fraction and the fraction of alkali-soluble P. In the loam and silt soils these parts are even higher, 94 per cent and 95 per cent, respectively. In both groups adding the variables $\mathrm{NH}_{4} \mathrm{Cl}$-soluble $\mathrm{P}$ and acid soluble $\mathrm{P}$, does not increase the variance which can be explained. In the clay soils less than one half of the variation in the Bray 1 test value is explainable by the variation in the $\mathrm{NH}_{4} \mathrm{~F}$-soluble fraction, taking into account the alkali-soluble $\mathrm{P}$ increases this part only to 54 per cent, but adding also the $\mathrm{NH}_{4} \mathrm{Cl}$-soluble $\mathrm{P}$, up to 70 per cent. Thus in the clay soils other factors seem to influence this test value to a marked degree. In the whole material three fourth of the variation may be explained by the $\mathrm{NH}_{4} \mathrm{~F}$-soluble $\mathrm{P}$, and 78 per cent by the combined effect of the three fractions dissolved before the acid treatment.

The variation in the Olsen test value explained by the variation in the $\mathrm{NH}_{4} \mathrm{~F}$ soluble $\mathrm{P}$ is markedly increased particularly in the clay soils when also the effect of the alkali-soluble fraction is included. In this group even the $\mathrm{NH}_{4} \mathrm{Cl}$-soluble $\mathrm{P}$ seems to be more important than in the other groups. The variation in these three fractions explain 78 per cent of the variation in this test value in the whole material, somewhat less in the sand and finesand soils and the clay soils, or 75 and 76 per cent respectively, but as much as 93 per cent in the loam and silt soils. The acid-soluble fractions seems to be of no importance. 
The acetate test values were relatively closely correlated with the $\mathrm{NH}_{4} \mathrm{Cl}$ soluble P. The coefficients of multiple determination show that taking into account this fraction in addition to the fractions of $\mathrm{NH}_{4} \mathrm{~F}$-soluble and alkali-soluble $\mathrm{P}$ markedly increases the part of the variaton in the acetate test values which may be explained, particularly in the loam and silt soils, clay soils and in the whole material. In the sand and finesand soils this fraction is less important, and it explains only 13 per cent of the variation left when the effects of the $\mathrm{NH}_{4} \mathrm{~F}$-soluble and alkalisoluble $\mathrm{P}$ has been taken into account. In the other soil groups this part varies from 46 to 75 per cent. It appears that the acid-soluble $\mathrm{P}$ may to a not quite insignificant extent explain the variation of this test value left unexplained by the other fractions in the clay soils.

The acetic acid test appears to be dependent on other factors than the fractions of inorganic P to a markedly higher degree than the other tests. Only in the sand and finesand soils somewhat more than one half of the variation may be explained by the fractions of $\mathrm{NH}_{4} \mathrm{~F}$-soluble, alkali-soluble and $\mathrm{NH}_{4} \mathrm{Cl}$-soluble $\mathrm{P}$, and adding the acid-soluble fraction increases this part to 62 per cent, or it explains 14 per cent of the part left. In all other groups only the acid-soluble fraction seems to be of importance, but e.g. in the clay soils about two thirds of the variation in the acetic acid test values cannot be explained by the variation in the four phosphorus fractions. The total correlation coefficients between this test value and the soil $\mathrm{pH}$ are fairly high. Yet, taking into account this variable does not significantly increase the part of the variation in the acetic acid test value which could be explained; for the whole material this part was increased only to 47 per cent.

\section{Discussion}

The soil tests studied differ from each other not only with respect to the extractant used but also with respect to the ratio of soil to solution and to the period of shaking. Thus, it is likely that during the short period of contact in the Bray 1 test, one minute, the resorption of extracted phosphorus is negligible, while this reaction may play a role in the tests in which the time of contact between the soil sample and the solution is longer. In the Olsen test the ratio of extractant to soil is twice as large as in the other tests.

Neutral $\mathrm{NH}_{4} \mathrm{~F}$ is supposed to dissolve aluminium-bound phosphate but not iron-bound phosphate, since the fluoroferrate is not stable under neutral or alkaline conditions (17). The acid solution used in the Bray 1 test is likely to attack both forms, and in addition, also some easily soluble calcium bound phosphate. In the present material this test value appeared to be closely correlated with the fraction soluble in the alkaline $\mathrm{NH}_{4} \mathrm{~F}$-solution in the sand and finesand soils and the loam and silt soils. This fraction may contain, in addition to the aluminium-bound forms, also dicalcium phosphate $(7,9,11)$. The alkali-bound forms supposed to be bound by iron, apparently played only a minor role in all soil groups, since the partial correlation coefficients between the Bray 1 test value and the alkali-soluble $\mathrm{P}$ after the 
elimination of the effect of the $\mathrm{NH}_{4} \mathrm{~F}$-soluble fraction were negative or lower than 0.36 . In the clay soils the relation between the Bray 1 test and the $\mathrm{NH}_{4} \mathrm{~F}$-soluble $\mathrm{P}$ was less close than in the other groups, but the fraction of the easily soluble $\mathrm{P}$, or $\mathrm{P}$ in the $\mathrm{NH}_{4} \mathrm{Cl}$ fraction, had to be taken into account. While in the groups of the coarser textured soils 83 or even 95 per cent of the variation in this test value could be explained on the basis of the variation in the fractions of $\mathrm{NH}_{4} \mathrm{~F}$-soluble and alkalisoluble $\mathrm{P}$, only 54 per cent was explained by the variation in these fractions in the clay soils. This difference is in accordance with the results reported by PRATT and BARBER (14). They suppose that in the clay soils the reagent is exhausted reacting with surfaces that expose phosphates otherwise not available to the fractioning reagents.

OLSEN et al. (13) introduced their method for the estimation of the available phosphorus in the calcareous soils. It is based on the increased solubility of calcium phosphates as a result of the decreasing $\mathrm{Ca}$ activity in the solution. They found that extraction with $\mathrm{NaHCO}_{3}$ removed about one half of the phosphorus on the surface of soil particles that readily exchanges with $\mathrm{P}^{32}$ in the soil solution, and that it minimizes secondary precipitation and adsorption reactions. It is likely that in acid soils mainly iron bound and aluminium bound surface phosphates are removed. The present results show that in these more or less acid soils, the acid-soluble phosphorus which apparently represents apatite like minerals did not influence the Olsen test values. In the whole material, the variation in the test value depends as much on the variation in the alkali-soluble $\mathrm{P}$ as on that in the $\mathrm{NH}_{4} \mathrm{~F}$-soluble $\mathrm{P}$. In the sand and finesand soils and in the loam and silt soils these two fractions appear to be almost equally important, but in the clay soils the connection with the alkali-soluble fraction seems to be more marked. Adding the $\mathrm{NH}_{4} \mathrm{Cl}$-soluble fraction increases particularly in these soils the part of the variation which can be explained. TYNER and DAvide (18) found that the relative capacity of the Bray 1 method and the Olsen test for extracting naturally occurring inorganic soil phosphorus forms was excellent for aluminium bound $\mathrm{P}$ and very slight for calcium bound $\mathrm{P}$, but that while the Bray 1 test has only a "fairn capacity to extract iron-bound $\mathrm{P}$, that of the Olsen test is "good". This is well in accordance with the results of the present study.

The low values of the acetate test show that they reflect the intensity factor rather than the capacity factor of the soil P-status, as the Bray test and the Olsen test probably do (cf. 19). The relatively high $\mathrm{pH}$ of the acid ammonium acetate solution, $\mathrm{pH} 4.65$, and the lack of any complex forming anion are likely to allow resorption of dissolved phosphate to occur during the extraction. Therefore, it is easy to understand that the acetate test values are most closely correlated with the $\mathrm{NH}_{4} \mathrm{Cl}$ soluble fraction. Only in the sand and finesand soils the relations with the alkalisoluble fraction and the $\mathrm{NH}_{4} \mathrm{~F}$-soluble fraction are more marked.

It has been claimed that acetic acid will dissolve calcium phosphates well, apatite and aluminium bound phosphate fairly well but iron bound phosphate only very slightly (5). Yet, on the basis of the present material, it seems that the acetic acid test values in the loam and silt soils and in the clay soils only depend on the acid-soluble fraction which is supposed to be mainly apatite like, but that no correlation exists between the test value and the $\mathrm{NH}_{4} \mathrm{~F}$-soluble fraction. In the sand and 
fine sand soils, on the other hand, even the alkali-soluble fraction appears to be of importance.

The purpose of the present study was to find out by statistical way on what kind of soil phosphorus the various test values will depend. It cannot give an answer to the question: which of the method is the best one. It is obvious that no one of these or other rapid chemical methods can alone measure the phosphorus status of a soil in spite of the fact that in some works fairly good correlation between the results of field or pot experiments and the test values have been obtained.

At the present, it seems that in acid soils particularly the $\mathrm{NH}_{4} \mathrm{~F}$-soluble fraction of phosphorus, and perhaps to somewhat lower degree also the alkali-soluble fraction, are those forms which contribute most to plant nutrition $(6,12)$. In our soils the soluble phosphorus applied is usually almost completely found in these two fractions $(7,9,10)$. Thus, the capacity factor of the soil phosphorus status may be reflected by a method which will measure the less intensively bound part of the phosphorus in the $\mathrm{NH}_{4} \mathrm{~F}$-soluble and in the alkali-soluble fractions. The results of the present study indicate that both the Bray 1 method and the Olsen method could be recommended for this purpose. The acetic acid test appears to be of no use in this respect, and the same is obviously true also with the acetate test. It is also apparent that the measurement of the intensity factor should be performed by a theoretically sounder method than the acetate test is.

\section{$S u m m$ ary}

The relation between the $\mathrm{P}$ test values obtained by four methods and the inorganic phosphorus fractions of soil was studied on the basis of a material consisting of 346 samples of mineral soils originating from the surface layer and from the deeper layers.

Fairly large differences were found in the results between the sand and finesand soils and the clay soils. The Bray 1 test gave higher average values in the former soils than in the latter group, and the contrary was true with the acetic acid test. On the average, the Bray 1 test and the Olsen test extracted equal amounts of phosphorus, the values of the acetate test were very low, and the acetic acid test values were between these except in the deeper layers of loam and silt soils and clay soils in which the acetic acid values tended to be higher than the other ones.

The Bray 1 test values and the Olsen test values were closely correlated with each other, and somewhat less closely correlated with the acetate values. The acetic acid values were correlated with the other test values only in the sand and fine sand soils.

The variation in the Bray 1 test values was most closely connected with the variation in the $\mathrm{NH}_{4} \mathrm{~F}$-soluble $\mathrm{P}$, and only in the clay soils the $\mathrm{NH}_{4} \mathrm{Cl}$-soluble and the alkali-soluble fractions appeared to be of importance. In the Olsen test both the $\mathrm{NH}_{4} \mathrm{~F}$-soluble and the alkali-soluble fractions had to be taken into account, in clay soils also the $\mathrm{NH}_{4} \mathrm{Cl}$-soluble fraction. Adding the acid-soluble fraction did not increase the part of the variation in these two test values which could be explained. 
The acetate test value was most closely associated with the $\mathrm{NH}_{4} \mathrm{Cl}$-soluble fraction, except in the sand and finesand soils where the alkali-soluble $\mathrm{P}$ appeared to be of importance. Taking into account the acid-soluble fraction increased to some extent the part of the variation in the acetate values which could be explained by the variation in the three other fractions. The variation in the acetic acid test value, on the other hand, appeared to depend only on the acid-soluble fraction in other groups than the sand and finesand soils. Less than one half of the variation in it could be explained by the variation in these four fractions or soil $\mathrm{pH}$.

It is suggested that the Bray 1 test and the Olsen test would be recommendable for the measurement of the capacity factor of the soil P status.

\section{REFERENCES}

(1) Al-AbBas, A. H. \& Barber, S. A. 1964. A soil test for phosphorus based upon fractionation of soil phosphorus. Soil Sci. Soc. Amer. Proc. 28: 218-224.

(2) Blanchar, R. W. \& Caldwell, A. C. 1964. Phosphorus uptake by plants and readily extractable phosphorus in soils. Agron. J. 56: 218-221.

(3) Bray, R. H. \& Kurtz, L. T. 1945. Determination of total, organic and available forms of phosphorus in soils. Soil Sci. 59: $39-45$.

(4) Chang, S. C. \& Jackson, M. L. 1957. Fractionation of soil phosphorus. Ibid. 84: 133-144.

(5) Ghani, M. O. \& Aleem, S. A. 1943. Fractionation of soil phosphorus II. Indian J. Agr. Sci. 13: $142-147$.

(6) Hanley, K. 1962. Soil phosphorus forms and their availability to plants. Irish J. Agr. Res. 1: $192-$ 193.

(7) KaIla, A. 1961. Fertilizer phosphorus in some Finnish soils. J. Sci Agr. Soc. Finland 33: 131-139.

(8) - 1963. Organic phosphorus in Finnish soils. Soil Sci. 95: 38-44.

(9) -1 1963. Fertilizer phosphorus in various fractions of soil phosphorus. J. Sci. Agr. Soc. Finland 35: $36-46$.

(10) -1965 . The fate of water-soluble phosphate applied to some mineral soils. Ibid. 37: 104-115

(11) Laverty, J. C. \& Maclean, E. O. 1961. Factors affecting yields and uptake of phosphorus by different crops: 3 . Soil. Sci. 91: 166-171.

(12) Mackenzie, A. F. 1962. Inorganic soil phosphorus fractions of some Ontario soils as studied using isotope exchange and solubility criteria. Canad. J. Soil Sci. 42: 150-156.

(13) Olsen, S. R. \& Cole, C. V. et al. 1954. Estimation of available phosphorus in soils by extraction with sodium bicarbonate. U.S.D.A. Cir. 939. 19 pp.

(14) Pratt, P. F. \& Garber, M. J. 1964. Correlations of phosphorus availability by chemical tests with inorganic phosphorus fractions. Soil Sci. Soc. Amer. Proc. 28: 23-26.

(15) Schofield, R. K. 1955. Can a precise meaning be given to wavailables soil phosphorus? Soils and Fertilizers XVIII: $373-375$.

(16) TerĀsvuori, A. 1953. Uber die Anwendung saurer Extraktionslösungen zur Bestimmung des Phosphordüngerbedarfs des Bodens, nebst theoretischen Erörterungen über den Phosphorzustand des Bodens. Publ. Staatl. Landw. Versuchsw. Finland N:r 141.

(17) Turner, R. C. \& Rice, H. M. 1952. Role of the fluoride ion in release of phosphate adsorbed by aluminium and iron hydroxides. Soil Sci, 74 : 141-148.

(18) Tyner, E. H. \& DAvide, J. G. 1962. Some criteria for evaluating soil phosphorus tests for lowland rice soils. Trans. Com. IV and V I.S.S.S.: $625-634$.

(19) Williams, E. G. 1962. Chemical soil tests as an aid to increased productivity. Ibid: 1-15. 
S E L O T U S :

\title{
ERÄITTEN FOSFORITESTIEN TULOSTEN RIIPPUVUUS MAAN EPÅORGAANISEN FOSFORIN FRAKTIOISTA
}

\author{
ARMi KaILA
}

Yliopiston maanviljelyskemian laitos, Pihlajamäki

Tutkimuksessa selvitettiin Bray 1-testin, Olsenin $\mathrm{NaHCO}_{3}$-testin, $0.5 \mathrm{n}$ etikkahapon ja viljavuustutkimuksessa käytetyn asetaatin antamien tulosten riippuvuutta maan epäorgaanisen fosforin fraktioista 346 kivennäismaanäytteen aineiston perusteella.

Eri maalajien välillä oli melko suuria eroja sekä testiarvoissa että niiden ja fosforifraktioiden suhteissa. Bray 1-testin tulosten vaihtelu oli selitettävissä ennen kaikkea ammoniumfluoridiin liukenevan fosforin vaihtelujen perusteella, vain savimaissa näyttivät helposti liukeneva ja emäkseen liukeneva fosfori olevan varteenotettavia. Olsenin testin tulokset näyttivät riippuvan sekä emäksen että fluoridin uuttamista fraktioista, savimaissa myös helposti liukenevasta fosforista. Kummassakaan testissä happoonliukenevalla fraktiolla ei näyttänyt olevan merkitystä. Matalat asetaattitestin tulokset olivat lähinnä korreloituneet helposti liukenevan fraktion kanssa paitsi hiekka- ja hietamaitten ryhmässä, jossa emäkseen liukeneva fosfori oli tärkeä. Myös happoon liukenevalla fosforilla saattoi olla jonkin verran merkitystä tässä testissä, mutta tämä fraktio oli ainoa, joka oli merkittävästi korreloitunut etikkahapon uuttamaan fosforiin muissa paitsi karkeimmissa maalajeissa.

Todettiin, että sekä Bray 1-testi että Olsenin $\mathrm{NaHCO}_{2}$-testi voinevat antaa verraten käyttökelpoisen arvion maan fosforitilanteen kapasiteettitekijästä. 